\begin{tabular}{|c|c|c|c|c|}
\hline & $\stackrel{\text { II us }}{P}$ & $\begin{array}{l}\text { stard flout } \\
\text { er cents. }\end{array}$ & $\begin{array}{c}\text { Mustard hulls } \\
\text { Pet cellt }\end{array}$ & $\begin{array}{l}\text { Whole seed. } \\
\text { Fer cent. }\end{array}$ \\
\hline \multirow[t]{3}{*}{ Total nitrogen } & Maximum & $9.6 \mathrm{I}$ & 5.00 & 7.75 \\
\hline & Minimum & 8.27 & 3.40 & $6,(\infty)$ \\
\hline & Mean & 9.69 & $4 . T 4$ & 7.09 \\
\hline \multirow[t]{3}{*}{ Crube fiber } & Maximum & 4.26 & 22.20 & 10.33 \\
\hline & Minimum & $2.3 !$ & $13 \cdot 74$ & 7.24 \\
\hline & Mean & 3.24 & IS.II & 805 \\
\hline \multirow{3}{*}{$\begin{array}{l}\text { Reducing matter } \\
\text { as dextrose, } \\
\text { by diastase }\end{array}$} & Maximum & 0.93 & 7.05 & $3 \cdot 13$ \\
\hline & Minimum & 0.00 & $1.5 I$ & I. 39 \\
\hline & Mean & 0.37 & 4.27 & 2.10 \\
\hline
\end{tabular}

One sample of commercial mustard flour comparatively free from starch, but condemned by the writer on account of added hulls, as shown unmistakably by the microscope, exhibited the following constants in the water-and fat-free substance:

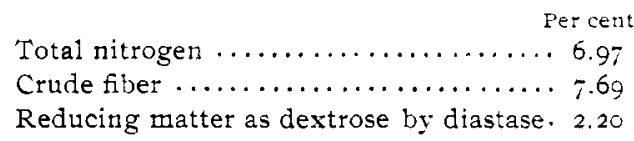

In this sample the microscope showed the fragments of hull to clearly form the chief feature of the mass, largely exceeding the material of the seed tissue.

Suggested Standards. - Based on the above analyses, the following standards are suggested for ground mustard, expressed on the moisture- and fat-free substance: Reducing material by diastase treatment should not exceed 2.5 per cent., expressed as dextrose ; crude fiber shonld not exceed 5 per cent. ; and total nitrogen should not be less than 8 per cent. As shown by the microscope, the sample should be free from more than minute traces of starch, and should not exhibit an excess of hulls over seed tissue.

\title{
THE COMPOSITION OF TURMERIC.
}

BY ALBERT E. LEACH.

Received Iuly 27, r9o4.

Turmeric (Curcuma longa of the family Zingiberaceae), while of chief interest to the analyst as an adulterant of other spices, possesses some value as a condiment in itself, forming, as it does, the chief ingredient of curry powder. Turmeric is a material especially adapted by its deep yellow color to intensify the color of mustard and ginger, especially when these spices are also 


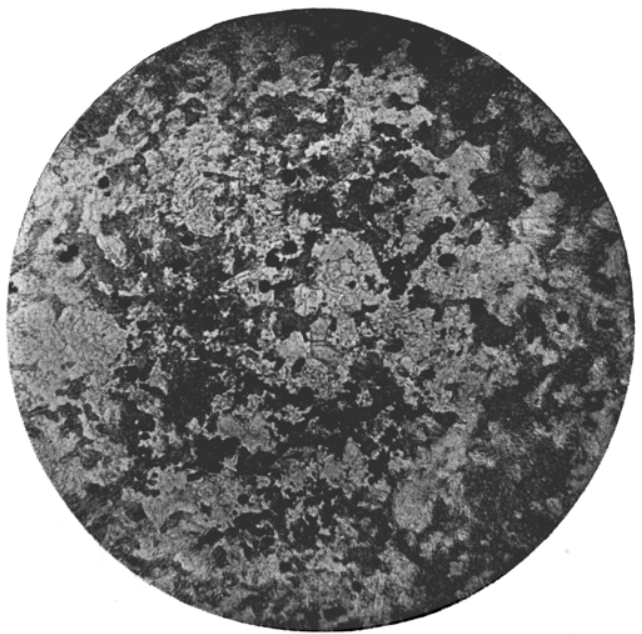

Fig. I.-Dakota mustard flour, $\mathrm{X}$ iro. Dark spots show starch grains of foreign weedseed, stained with iodine.

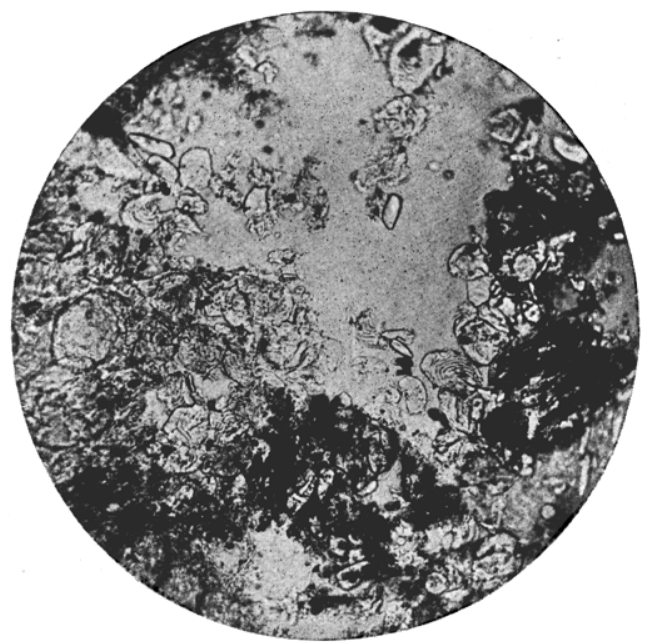

Fig. 2.-Powdered turmeric, X r Io. Showing starch grains, fragments of cell tissue, coloring-matter, etc. 

zdulterated with the lighter colored cereal starches; hence it is very commonly found in these spices, both with and without other adulterants.

It is sometimes used, moreover, in small quantities in adulterated cayenne, mace, and various other spices, to counteract the colors of other dyestuffs, such, for instance, as ground redwood, which in itself would be too intense, if used as the sole artificial coloring agent in cayenne.

The chief ingredients of turmeric are starch, a slightly fluorescent, orange-yellow, volatile oil, a deep yellow coloring-matter (curcumin), soluble in alcohol, but insoluble in cold water, cellulose and a gum.

There are few, if any, records of the satisfactory analysis of turmeric, with the exception of two varieties of Bengal and Madras turmeric recorded in the recently issued 4 th edition of König's Nahrungs und Genussmittel. ${ }^{1}$

The following are results of analyses made in the writer's laboratory of three varieties of turmeric commonly used in this country, the samples being ground in each case from large fragments of the root-stock.

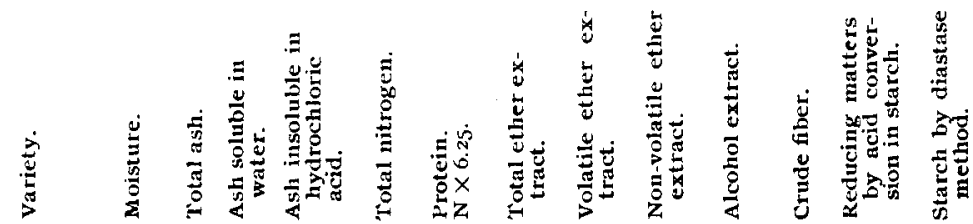

China..9.03 6.72 5.20 O.I I I.73 I0.8I 10.86 2.0I $8.84 \quad 9.22 \quad 4.4548 .6940 .05$

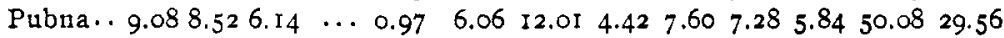
Alleppi. $8.075 .994 .74 \quad \cdots \quad 1.56 \quad 9.75 \quad 10.66 \quad 3.16 \quad 7.5$ I $4.37 \quad 5.83 \quad 50.44 \quad 33.03$ $\begin{array}{lllllllllllllll}\text { Average } & 8.73 & 7.07 & 5.36 & \ldots & \text { I.42 } & 8.88 & \text { II.I } & 3.19 & 7.98 & 6.96 & 5.37 & 49.73 & 34.21\end{array}$

\section{MALT ANALYSIS.}

BY H. AUG. HUNTCKE.

Received July 23, 1904 .

I. DETERMINATION OF EXTRACT.

WHILE great quantities of malt are evaluated by inspection, it cannot be said that any considerable amount is purchased by analysis. The purchaser, while largely guided by the color, justly

vo1. II., p. 1063 . 